\title{
Sulfur, Selenium, Tellurium, and Copper Systematics in the Manus Back-Arc Basin
}

\author{
LAUREN R. GOROJOVSKY ${ }^{1 *}$, OLIVIER ALARD ${ }^{1 \& 2}$, SIMON
} TURNER ${ }^{1}$

${ }^{1}$ CCFS \& GEMOC, Dept. of Earth and Environmental Science, Macquarie University, Sydney, 2109, Australia. lauren.gorojovsky@mq.edu.au

${ }^{2}$ Géosciences Montpellier, CNRS, France (oalard@univ$\underline{\text { montp2.fr) }}$

Sulfide or sulfate largely dictates the behaviour/transport of chalcophiles and siderophile elements in magmas. The sulfate to sulfide ratio is related to oxygen fugacity. Magmas at convergent margins are overall more oxidised than in other tectonic settings (FMQ +1 to FMQ +3 ). $\mathrm{S}$, and markedly $\mathrm{Se}$ and $\mathrm{Te}$ form a suite of elements that have been conventionally regarded as analytically challenging. This is owing to severe polyatomic interferences during typical ICP-MS analysis and their low concentrations in natural glasses that are close to or below typical detection limits for LA-ICP-MS. Yet the strongly chalcophile behaviour of $\mathrm{Se}$ and $\mathrm{Te}$, and $\mathrm{Cu}$, make these elements an ideal proxy for monitoring the behaviour of $\mathrm{S}$ in magmatic systems.

Twenty-nine submarine glasses from the Manus Basin associated with the subduction of the Solomon oceanic plate have been analysed for $\mathrm{S}, \mathrm{Se}, \mathrm{Cu}$ and $\mathrm{Te}$ contents using enhanced LA-ICP-MS/MS techniques developed for this study. MORB, BABB, and Arc lavas have been identified as the main magma types in this study area and range between $3.4-8.7 \mathrm{wt} \% \mathrm{MgO}\left(49.5-57.3 \mathrm{wt} \% \mathrm{SiO}_{2}\right)$. We find no obvious indication of $\mathrm{S}$ loss via degassing or seawater alteration. Sulfur contents range between $364-1196 \mu \mathrm{g} \mathrm{g}^{-1}$, where lowest $\mathrm{S}$ contents are found in the most evolved samples. This is whilst maintaining PM-like $(\sim 3000) \mathrm{S} / \mathrm{Se}$ ratios across all magma types ( 3300). HFSE depletion trends reveal a depleted MORB mantle source, where magmas evolve as sulfide-undersaturated melts. Further, $\mathrm{Cu}$ and Te contents positively correlate with LILE enrichments, indicating that their contents are systematically tied to the increased influence of slab-derived components into the Manus Basin magma source.

Despite being oxidised (up to FMQ +2) and thus able to accommodate higher $\mathrm{S}$ contents as $\mathrm{S}^{6+}$ within the melt, Manus Basin magmas are not enriched in $\mathrm{S}$ and do not show significant variation of the $\mathrm{S} / \mathrm{Se}$ ratio. 